Bull. Fac. Agric, Cairo Univ., 71:85-93 (2020).

\title{
IMPACT OF SOME SOIL HERBICIDES AS PRE-EMERGENCE AND PRE-PLANTING APPLICATION ON SORGHUM (Sorghum bicolor L. ) PRODUCTIVITY AND ASSOCIATED WEEDS.
}

\author{
(Received: 26. 6 .2020) \\ By \\ Rasha G.M. Abo El-Hassan and A.M.A. Hassanein \\ Weed Control Central Laboratory Research, Agricultural Research Center, Giza, Egypt
}

\begin{abstract}
Two field experiments were conducted during two successive seasons (2018 and 2019), at Sids Agricultural Research Station, Bani Swif, Egypt, to evaluate efficacy and selectivity of some soilapplied herbicides (Butralin at $120 \mathrm{~g}$, Pendimethalin at $773.5 \mathrm{~g}$ and Acetochlor at $840 \mathrm{~g}$ a.i./fed.). In addition, hand hoeing (twice) and weed check (control), under influence of different application methods as pre-emergence (experiment 1) or pre-planting (experiment 2) on vegetative growth and grain sorghum were simultaneously examined. Each experiment was laid out in a Randomized Complete Blocks Design, with four replicates. The results showed that there was no difference on efficacy of weed control between two application methods of soil-herbicides whereas there was satisfactory controlling effect of total weeds in both seasons. Also, the results revealed that in the preemergence application gave the highest injury in vegetative growth, which were inversely related between the vegetative growth and yield and its components. Whereas the increasing reduction in number of plants/plot, yield and its components decreased. On the contrary, in pre-planting application there was no adverse effect on vegetative growth, rather there was a positive correlation, whereas increases in number of plants/plot, yield and its components increased, in both seasons. Generally, it is concluded that, sorghum vegetative growth, yield and its components were not affected by these herbicides, so that appear to have good potential for controlling effect on weeds and selectivity of grain sorghum when applied pre-planting (14 days from application) but (pre-emergence) is risky.
\end{abstract}

Key words: Sorghum (Sorghum bicolor (L.) Moench), Soil-applied Herbicide, Pre-emergence, Preplanting, Herbicide residue, Weed control.

\section{INTRODUCTION}

Sorghum (Sorghum bicolor (L.) Moench) is a cereal grain originated in Africa and grown in tropical, subtropical, and arid regions (Dykes et al., 2013). Today, sorghum is grown all over the world because it has been found to be a drought tolerant crop with better water use efficiency compared to the cereals, maize and rice (Moges et al., 2007). In Egypt, sorghum is considered as one of the most important summer cereals for both human, animal consumption and industrial products (Dahlberg et al., 2011; Dicko et al., 2006 and Awika \& Rooney, 2004). In addition, sorghum occupies about 14,7961 ha, producing up to 727,648 tons of grains (FAO, 2017).

Weeds are the most serious pests reducing the growth, yield and quality of grain sorghum by competing with sorghum for nutrients, water, and light (Grichar et al., 2005). However, sorghum is a poor competitor against weeds due to slow growth and poor vigor for the first threefour weeks after emergence, although it eventually establishes a dense canopy (Peerzada et al., 2017). Yield losses due to weed competition ranged between 15-55\% (Everaarts, 1993). In addition, yield losses reached $85 \%$ for grain sorghum and $81 \%$ for forage sorghum (Andres et al., 2009 and Rodrigues et al., 2010).

The main problem of sorghum is its high sensitivity to graminacouse herbicides, which is why mechanical weed control must be carried out, which makes production more expensive (Bibard, 2004)

Herbicides recommendations for grain sorghum are limited (Mishra, 2015) because they are highly toxic to sorghum and therefore cannot be applied without specific antidotes or safeness to protect sorghum from the phytotoxic effects of herbicides (Vajs et al., 2007; Delchev and Barakova, 2018). In Egypt, there are no 
officially recommended herbicides for controlling weeds on sorghum. Even when used, maize herbicides may provide effective weed control but they can injure the sorghum crop. Therefore, problems for controlling graminacouse weeds on grain sorghum requires the introduction of new concept technology based on the use of herbicides without causing damages to sorghum. It makes possible controlling annual graminacouse weeds to be carried out by herbicides as (dual, stomp and harness).

Thus, the current research aimed to develop a technique based on the application of soil applied herbicides (without antidotes/safeness) during the period after herbicides application, before sorghum grains sowing (called Improved method / pre-planting); is considered, the key practice for controlling weeds without injury to the crop compared to the Traditional method ( pre-emergence). Also, to study the effects of these herbicides on sorghum safety, productivity and associated weeds.

\section{MATERIALS AND METHODS}

Two Field experiments were carried out during successive summer seasons of 2018 and 2019, at Sids Agricultural Research Station, Beni-Suef Governorate, Agricultural Research Centre (A.R.C.), Egypt, to evaluate the efficiency of some soil applied herbicides on weed control and sorghum safety under two different sowing methods, namely, 1- Traditional sowing (pre-emergence) as experiment (1), and 2- Improved sowing (pre-planting) as experiment (2). Moreover, to study the effects of these herbicides on sorghum productivity and associated weeds. Each experiment was laid out in a randomized complete block design (RCBD) with four replicates. The Each plot area was 10.5 $\mathrm{m}^{2}$ (5 rows X $3.5 \mathrm{~m}$ length). The row-to row and plant-to-plant distances were $60 \mathrm{~cm}$ and $20 \mathrm{~cm}$, respectively.

In both field experiments, herbicide treatments were as follows:
1. Butralin "Amex $48 \%$ EC" used at the recommended rate $2.5 \mathrm{~L} /$ fed.

2. Pendimethalin "Stomp Extra 45.5\% CS" used at the recommended rate $1.7 \mathrm{~L} / \mathrm{fed}$.

3. Acetochlor "Harness $84 \%$ EC" used at the recommended rate $1.0 \mathrm{~L} /$ fed.

4. Hand hoeing Twice: at 20 and 45 days after sowing (DAS).

5. Untreated (control).

The herbicide treatments are explained in Table 2 .

\subsection{Herbicides application}

Experiment 1: the herbicides (Butralin, Pendimethalin and Acetochlor) were applied as Pre-emergence after sowing sorghum grains and immediately prior to irrigation.

Experiment 2: the same previous herbicides were applied before sowing sorghum grains.

The herbicides were sprayed, by Knapsack sprayer CP3, with water (200 Liters per feddan) in both experiments.

In both experiments, Sorghum cultivars "Dorado Variety" obtained from the Agriculture Research Center, Giza, Egypt, Sorghum grains were sowing manually on one side in hills at the rate of $20 \mathrm{~kg} / \mathrm{fed}$., and sawn on the $1^{\text {st }}$ week of June in Experiment 1 (pre-emergence application), where grains were sown before spraying herbicides and irrigation. In the Experiment 2 (pre-planting application), grains were sawn after 14 days from spraying herbicides and sowing-irrigation.

The seedling were thinned to one plant per hill before the $1^{s t}$ irrigation in each experiments.

Harvesting was on October the $10^{\text {th }}$ (Experiment 1) and $20^{\text {th }}$ (Experiment 2) in both seasons. The cultural practices for sorghum production were conducted according to local recommendations. The soil texture in both experiments was clay loam. Chemical and Physical analysis of the soil were carried out according to (Jackson, 1960) and (Wilde et al., 1985) and data are shown in Table (1).

Table (1): Mechanical and chemical analysis of the experimental soil.

\begin{tabular}{|c|c|c|c|c|c|c|c|c|c|c|c|c|}
\hline \multicolumn{4}{|c|}{ Mechanical analysis } & \multicolumn{4}{c|}{ Chemical analysis } & \multicolumn{5}{|c|}{ Available nutrients } \\
\hline $\begin{array}{c}\text { Sand } \\
\%\end{array}$ & $\begin{array}{c}\text { Silt } \\
\%\end{array}$ & $\begin{array}{c}\text { Clay } \\
\%\end{array}$ & $\begin{array}{c}\text { Textur } \\
\text { e }\end{array}$ & OM & PH & $\begin{array}{c}\text { E.C } \\
\text { mmhos/cm }\end{array}$ & $\begin{array}{c}\text { N } \\
\%\end{array}$ & $\begin{array}{c}\text { P } \\
(\mathbf{p p m})\end{array}$ & $\begin{array}{c}\text { K } \\
(\mathbf{p p m})\end{array}$ & $\begin{array}{c}\text { Fe } \\
(\mathbf{p p m})\end{array}$ & $\begin{array}{c}\text { Mn } \\
(\mathbf{p p m})\end{array}$ & $\begin{array}{c}\text { Zn } \\
(\mathbf{p p m})\end{array}$ \\
\hline 19.8 & $\mathbf{3 0 . 8}$ & 49.4 & $\begin{array}{c}\text { Clay } \\
\text { loam }\end{array}$ & $\mathbf{1 . 5 5}$ & 7.72 & 1.1 & $\mathbf{0 . 1}$ & $\mathbf{2 9 . 2}$ & $\mathbf{3 7 0 . 1}$ & $\mathbf{3 3 . 0}$ & $\mathbf{1 9 . 0}$ & 5.7 \\
\hline
\end{tabular}


Table (2): Trade, common and chemical names, family group and site of action of the herbicides according to the pesticide manual (2012) and the number of group according to (WSSA, 2011) classification.

\begin{tabular}{|c|c|c|c|c|c|}
\hline $\begin{array}{l}\text { Trade } \\
\text { name }\end{array}$ & $\begin{array}{c}\text { Common } \\
\text { name }\end{array}$ & Chemical name & Family group & $\begin{array}{l}\text { Site of } \\
\text { Action }\end{array}$ & $\begin{array}{l}\text { WSSA } \\
\text { Group }\end{array}$ \\
\hline $\begin{array}{l}\text { Amex } 48 \% \\
\text { EC }\end{array}$ & Butraline & $\begin{array}{l}\text { [[4-(1,1-dimethylethyl)- } \\
\text { N-(1-methylpropyl)-2,6- } \\
\text { dinitro benzenamine }\end{array}$ & Dinitroanilines & \multirow{3}{*}{$\begin{array}{l}\text { Inh. Cell } \\
\text { division }\end{array}$} & \multirow{2}{*}{ 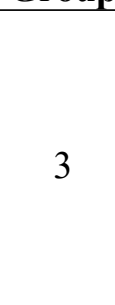 } \\
\hline $\begin{array}{l}\text { Stomp } \\
\text { Extra } 45.5 \% \\
\text { CS }\end{array}$ & Pendimethalin & $\begin{array}{c}\text { [ } \mathrm{N} \text { - (1-ethylpropyl) }-3, \\
\text { 4-dimethyl-2, 6-dinitro } \\
\text { benzenamine] }\end{array}$ & Dinitroanilines & & \\
\hline $\begin{array}{l}\text { Harness } \\
84 \% \text { EC }\end{array}$ & Acetochlor & $\begin{array}{c}\text { [2-chloro -N- } \\
\text { (ethoxymethyl) - N - } \\
\text { (2-ethyl-6-methyl } \\
\text { phenyl) acetamide }\end{array}$ & chloroacetamide & & 15 \\
\hline
\end{tabular}

\subsection{The following data were recorded}

\subsubsection{Herbicides residues}

Sampling of herbicides residues (Butralin, Pendimethalin and Acetochlor) in soil were taken at depths $(7 \mathrm{~cm})$ and different time points (zero time and after 14 days from herbicide application) in both experiments. Herbicides residues were determined according to the method of (BS/EN (15662:2018)) with some modifications in the Central Laboratory for Pesticides, Agriculture Research Center, Dokki, Giza, Egypt.

\subsubsection{Vegetative growth characters}

2.2.2.1. Establishment of the number of plants per plot: after 30 days from herbicide treatments.

2.2.2.2. Plant height $(\mathbf{c m})$ : after 30 days from herbicide treatments.

2.2.3. Weeding: Weeds were hand pulled from one square meter chosen at random from each plot at 60 days after application (DAA) of herbicide treatments, identified according to Täckholm (1974), and classified into their species and divided into the following groups:

1- Annual broad-leaved weeds.

2- Annual grassy weeds.

3- Total of annual weeds.

Weed control efficiency (WCE) was calculated as follows:

$$
\text { FWC - FWT }
$$

$\mathrm{WCE} \%=\frac{}{\text { FWC }} \times 100$

Where, $\mathrm{FWC}=$ Fresh weight of weeds from the control plot and FWT $=$ Fresh weight of weeds from the treated plot.

\subsubsection{Yield and its Components}

At harvest, ten plants were randomly selected from each plot to study the following characteristics: panicle length $(\mathrm{cm})$, weight of grains (g)/panicle and weight of 1000 grains $(\mathrm{g})$. Weight of grains of central $4 \mathrm{~m}^{2}$ of each plot (the weight were corrected to $15.5 \%$ moisture) and converted to ardab per feddan ( $1 \mathrm{ardab}=140 \mathrm{~kg}$ ) to determine Grain yield per feddan $\left(4,200 \mathrm{~m}^{2}\right)$.

\subsubsection{Statistical Analysis}

All data were statistically analyzed according to technique of Analysis of Variance (ANOVA) for the randomized complete block design with four replicates as mentioned by (Gomez and Gomez 1984). Duncan (1955) multiple range tests were used for the comparison between means. All statistical analysis was performed using analysis of variance technique by means of MSTAT-C computer software package (Snedecor and Cochran 1980).

\section{RESULTS AND DISCUSSION}

\subsection{Effect of weed control treatments on:}

\subsubsection{Weeds}

In both experimental sites during both growing seasons of sorghum the major weeds flora identification and classification included Portulaca oleracea L., Amaranthus cruentus L., Xanthium strumarium L., and Euphorbia geniculata L., as broad-leaf weeds. While Brachiaria repans L., Dinebra retroflexa L. and 
Echinochloa colonum L. were identified as grasses. (Table 3) showed that all herbicide treatments in both pre-emergence and preplanting applications provided better broad spectrum of weed control. In the pre-emergence herbicides application (pendimethaline at $773.5 \mathrm{~g}$, Acetochlor at $840 \mathrm{~g}$ and butralin at $120 \mathrm{~g}$ a.i /fed.) gave satisfactory controlling effect of total weeds whereas reached to $(88.5,86.6$ and $83.3 \%$, respectively). Similar trend was noticed in the pre-planting application, where it reached to $90.8,89.2$ and $84.2 \%$, respectively, in the first season. The same trend was observed in the second season. There was no difference in weed control efficacy between pre-emergence and preplanting methods in each experiment. This is because the herbicides applications in both methods were carried out under similar conditions. Consequently, the activity of herbicides on the target weed species was similar tested in research study for sorghum crop. In this respect, (James et al., 2005) revealed that the combinations (Mesotrione, s-metochlore and Atrazine) and (Mesotrione, s-metochlore) provided better broad spectrum weed control when applied as pre-planting (10 or 20 days before planting) than when applied preemergence. The efficacy of herbicides on weed control referred to inhibition cell division whereas, Dinitroaniline family (Pendimethalin and Butralin) are interfering with the formation of microtubules by binding to tubulin molecules (Appleby and Valverde, 1989), consequently, inhibition of main root and to greater extent lateral root formation resulting in short and thick lateral roots. In addition, Chloroacetamide family (Acetochlor) is inhibition cell division by another way as blocking biosynthesis of very long chain fatty acids (Schmalfuss et al., 2000 and Böger et al., 2000).

Table (3): Effect of weed control treatments on fresh total weeds $\left(\mathrm{g} / \mathrm{m}^{2}\right)$ in two experiments of application methods in both seasons.

\begin{tabular}{|c|c|c|c|c|c|c|c|c|c|c|}
\hline \multirow{3}{*}{ Treatments } & \multirow{3}{*}{$\begin{array}{l}\text { Rate } \\
\text { / fed. }\end{array}$} & \multirow{3}{*}{$\begin{array}{l}\text { g a.i./ } \\
\text { fed. }\end{array}$} & \multicolumn{4}{|c|}{$\begin{array}{c}\text { Exp.1 } \\
\text { Pre-emergence application } \\
\text { (traditional method) }\end{array}$} & \multicolumn{4}{|c|}{$\begin{array}{c}\text { Exp.2 } \\
\text { Pre-planting application } \\
\text { (improved method) }\end{array}$} \\
\hline & & & \multicolumn{2}{|c|}{ season 2018} & \multicolumn{2}{|c|}{ season 2019} & \multicolumn{2}{|c|}{ season 2018} & \multicolumn{2}{|c|}{ season 2019} \\
\hline & & & Mean & $\%$ & Mean & $\%$ & Mean & $\%$ & Mean & $\%$ \\
\hline $\begin{array}{l}\text { Butralin } \\
\text { (Amex) }\end{array}$ & 2.51 & 120 & $380.3 \mathrm{~b}$ & 83.3 & $491.0 \mathrm{~b}$ & 80.6 & $403.5 \mathrm{~b}$ & 84.2 & $352.3 b$ & 86.3 \\
\hline $\begin{array}{l}\text { Pendimethaline } \\
\text { (stonp Extera) }\end{array}$ & 1.71 & 773.5 & $262.5 \mathrm{~b}$ & 88.5 & $298.3 \mathrm{~b}$ & 88.2 & $233.8 \mathrm{~b}$ & 90.8 & $201.5 b$ & 92.2 \\
\hline $\begin{array}{l}\text { Acetochlor } \\
\text { (Harnnes) }\end{array}$ & 11 & 840 & $306.0 \mathrm{~b}$ & 86.6 & $384.3 \mathrm{~b}$ & 84.8 & $275.8 \mathrm{~b}$ & 89.2 & $287 \mathrm{~b}$ & 88.9 \\
\hline \multicolumn{3}{|c|}{ Hand hoeing (twice) } & $397.5 \mathrm{~b}$ & 82.6 & $479.0 \mathrm{~b}$ & 81.0 & $426.5 \mathrm{~b}$ & 83.3 & $457.3 \mathrm{~b}$ & 82.3 \\
\hline \multicolumn{3}{|c|}{ Untreated weed } & $2279.0 \mathrm{a}$ & 0.0 & $2525.8 \mathrm{a}$ & 0.0 & $2548.8 \mathrm{a}$ & 0.0 & $2577 \mathrm{a}$ & 0.0 \\
\hline
\end{tabular}

Any two means in the same column sharing same letters did not differ significantly by Duncan at $5 \%$ level of probability.

in both methods. These results are in harmony with (Gerik et al., 2003) found that the applications of Pre-emergence herbicides (Dual, Lasso and Frontier) are widely used to control weeds in sorghum. Also, (Khaffagy et al., 2015) found that application of pre-emergence herbicides (Acetochlor at $900 \mathrm{~g}^{\mathrm{a}}$ a. $\mathrm{fed}^{-1}$ (Vern), Acetochlor at $840 \mathrm{~g}$ a.i.fed ${ }^{-1}$ (Harness) and Pendimethaline at $773.5 \mathrm{~g}$ a.i.fed ${ }^{-1}$ (Stomp Extra) gave satisfactory effect on controlling total weeds more than $80 \%$. In addition, (Takano et al., 2016) indicated that Metazachlor and Alachlor recommended for controlling weeds in maize, were used in sorghum by producers due to the affinity between both crops, and being

\subsubsection{Vegetative growth characters}

Results in Table (4) revealed that in the pre-emergence herbicides application ((pendimethaline at $773.5 \mathrm{~g}$, Acetochlor at $840 \mathrm{~g}$ and butralin at $120 \mathrm{~g}$ a.i /fed.)) gave significantly the highest injury number of sorghum plants per plot, whereas, the reduction percentage in the previous herbicides were $(23.8,23.4$ and $37.4 \%$, respectively), compared to hand hoeing treatment, also they gave shorter plant height $(22.30,22.33$ and $21.75 \mathrm{~cm}$, respectively), in the first season. The same trend was in the second season. Therefore, the hand hoeing treatment gave significantly superiority in vegetative growth than herbicides treatments. 
On the contrary, results in Table (5) showed that in the pre-planting method had no adverse effect on the number of sorghum plants per plot and plant height $(\mathrm{cm})$, also, there were no significant differences between each of the previous herbicides and hand hoeing treatment in both seasons.

The damage of Pre-emergence herbicide application referred to sorghum seedling are able to take up the herbicide at a rapid rate but are not able to metabolize as fast as they can be absorbed (Hartzler, 2020). Therefore, the results in Table (6) showed that the herbicide amounts (Butralin, Pendimethalin and Acetochlor) at zero time (in both applications) were high, reaching to $5.13,2.5$ and $3.92 \mathrm{mg} / \mathrm{kg}$, respectively. Thus, pre-emergence application only causes toxicity and damage to sorghum seedling.

In contrast, the results in Table (6) showed that the herbicide residues at 14 (days from application) in the pre-planting method were of smaller amount (reaching to $1.01,0.88$ and 0.28 $\mathrm{mg} / \mathrm{kg}$, respectively), than the amount at zero time. In addition, results in Fig. (1) confirmed that the reduction percentage of the amount of herbicides residues reached 80.3, 64.8 and $92.9 \%$, respectively, compared to zero time. Moomaw et al. (1992) and Hartzler (2020) explained that the herbicides degradation in preplanting application take long period (14 days) resulting in increases in metabolism, reducing phytotoxicity. While, in pre-emergence, it is short period. Thus, the pre-planting method was effective for weed control and safe for sorghum plants compared to pre-emergence method which was effective for weed control but injury sorghum plants.

Table (4): Effect of weed control treatments on the vegetative growth after 30 days from applied herbicides in Pre-emergence application in both seasons.

\begin{tabular}{|c|c|c|c|c|c|c|}
\hline \multirow{3}{*}{ Treatments } & \multirow{3}{*}{$\begin{array}{l}\text { Rate / } \\
\text { fed. }\end{array}$} & \multirow{3}{*}{$\begin{array}{l}\text { g a.i./ } \\
\text { fed. }\end{array}$} & \multicolumn{4}{|c|}{ Pre-emergence application (traditional method) } \\
\hline & & & \multicolumn{2}{|c|}{ Number of plants/plot } & \multicolumn{2}{|c|}{ Plant height $(\mathrm{cm})$} \\
\hline & & & 2018 season & 2019 season & 2018 season & 2019 season \\
\hline Butralin (Amex) & 2.51 & 120 & $24.8 \mathrm{~b}$ & $22.5 \mathrm{~b}$ & $21.75 \mathrm{~b}$ & $22.5 \mathrm{~b}$ \\
\hline $\begin{array}{l}\text { Pendimethaline } \\
\text { (Stomp Extera) }\end{array}$ & 1.71 & 773.5 & $15.8 \mathrm{c}$ & $17.3 \mathrm{~d}$ & $22.30 \mathrm{~b}$ & $23.5 \mathrm{~b}$ \\
\hline $\begin{array}{l}\text { Acetochlor } \\
\text { (Harnnes) }\end{array}$ & 11 & 840 & $15.5 \mathrm{c}$ & $18.8 \mathrm{c}$ & $22.33 \mathrm{~b}$ & $22.5 \mathrm{~b}$ \\
\hline \multicolumn{3}{|c|}{ Hand hoeing (twice) } & $66.3 \mathrm{a}$ & $66.3 \mathrm{a}$ & $26.75 \mathrm{a}$ & $27.5 \mathrm{a}$ \\
\hline \multicolumn{3}{|l|}{ Untreated weed } & $66.0 \mathrm{a}$ & $66.0 \mathrm{a}$ & $22.13 \mathrm{~b}$ & $21.8 \mathrm{~b}$ \\
\hline
\end{tabular}

Any two means in the same column sharing the same letters did not differ significantly by Duncan at $5 \%$ level of probability.

Table (5): Effect of weed control treatments on the vegetative growth after 30 days from applied herbicides in pre-planting application in both seasons.

\begin{tabular}{|c|c|c|c|c|c|c|}
\hline \multirow{3}{*}{ Treatments } & \multirow{3}{*}{$\begin{array}{c}\text { Rate / } \\
\text { fed. }\end{array}$} & \multirow{3}{*}{$\begin{array}{l}\text { g a.i./ } \\
\text { fed. }\end{array}$} & \multicolumn{4}{|c|}{ Pre-planting application (improved method) } \\
\hline & & & \multicolumn{2}{|c|}{ Number of plants/plot } & \multicolumn{2}{|c|}{ Plant height (cm) } \\
\hline & & & 2018 season & 2019 season & 2018 season & 2019 season \\
\hline Butralin (Amex ) & 2.51 & 120 & $66.3 \mathrm{a}$ & $67.3 \mathrm{a}$ & $26.5 \mathrm{a}$ & $27.3 \mathrm{a}$ \\
\hline $\begin{array}{l}\text { Pendimethaline (stomp } \\
\text { Extera) }\end{array}$ & 1.71 & 773.5 & $66.3 \mathrm{a}$ & $67.50 \mathrm{a}$ & $27.0 \mathrm{a}$ & $27.9 \mathrm{a}$ \\
\hline Acetochlor (Harnnes) & 11 & 840 & $66.3 \mathrm{a}$ & $67.3 \mathrm{a}$ & $27.0 \mathrm{a}$ & $27.5 \mathrm{a}$ \\
\hline \multicolumn{3}{|l|}{ Hand hoeing (twice) } & $66.3 \mathrm{a}$ & $67.3 \mathrm{a}$ & $26.0 \mathrm{a}$ & $26.8 \mathrm{a}$ \\
\hline \multicolumn{3}{|l|}{ Untreated weed } & $66.3 \mathrm{a}$ & $67.3 \mathrm{a}$ & $23.5 \mathrm{~b}$ & $24.3 \mathrm{~b}$ \\
\hline
\end{tabular}

Any two means in the same column sharing the same letters did not differ significantly by Duncan at $5 \%$ level of probability. 
Table (6): Herbicides amount (mg / kg) in soil at two times of taken sample from herbicides application.

\begin{tabular}{|c|c|c|c|c|}
\hline Herbicides & $\begin{array}{c}\text { Rate / } \\
\text { fed. }\end{array}$ & $\begin{array}{c}\text { g a.i./ } \\
\text { fed. }\end{array}$ & $\begin{array}{c}\text { Herbicides residue } \\
\text { at zero time }\end{array}$ & $\begin{array}{c}\text { Herbicide residues after 14 } \\
\text { days from application }\end{array}$ \\
\hline $\begin{array}{c}\text { Amex 48\% EC } \\
\text { (butralin) }\end{array}$ & 2.51 & 120 & 5.13 & 1.01 \\
\hline $\begin{array}{c}\text { Stomp extra 45.5\% CS } \\
\text { (Pendimethalin) }\end{array}$ & 1.71 & 773.5 & 2.5 & 0.88 \\
\hline $\begin{array}{c}\text { Harness84\%EC } \\
\text { (Acetochlor) }\end{array}$ & 11 & 840 & 3.92 & 0.28 \\
\hline
\end{tabular}

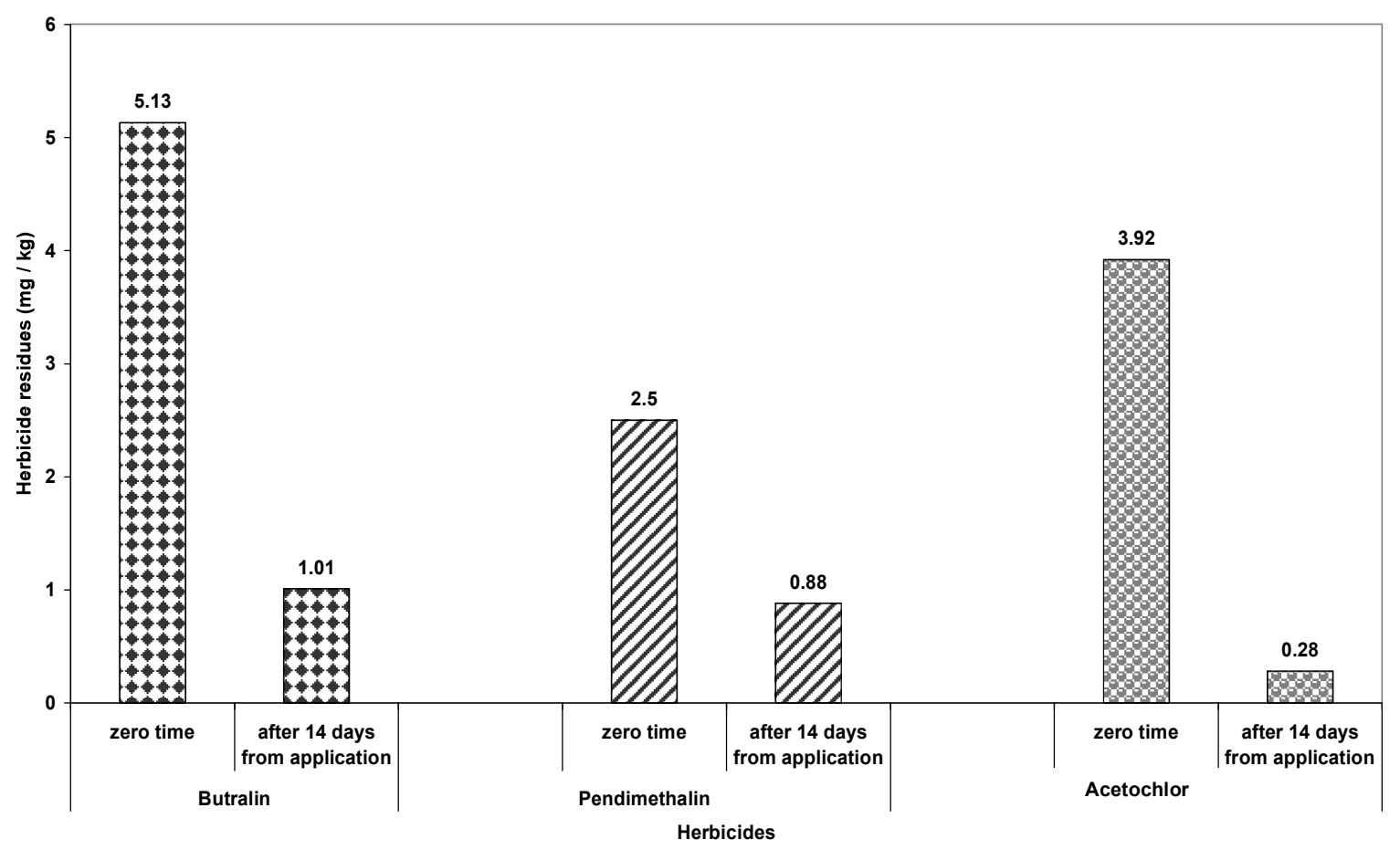

Fig. (1): Herbicides amount (mg / kg) in soil for butralin, pendimethaline and Acetochlor at zero time and after 14 days from application.

\subsubsection{Yield and its components}

Yield and its components were a reflection of the effect of herbicides treatments on the number of plants per plot in either of the two methods. Data in Tables ( 7 and 8 ) revealed that in the preemergence herbicides application (Butralin at $120 \mathrm{~g}$, Pendimethaline at $773.5 \mathrm{~g}$ and Acetochlor at $840 \mathrm{~g}$ a.i./fed.) were inversely related between the number of plants per plot and yield and its components (panicle length $(\mathrm{cm})$, weight of grains $(\mathrm{g}) /$ panicle and weight of 1000 grains (g)). Thus as the reduction on the number of plants per plot increases, yield and its components decreased, whereas, the reduction on grain yield reached to $(2.94,1.69$ and 1.74 ardab/fed., respectively) compared to the hand hoeing in the first season. The same trend was in the second season. This result agree with (Gerik et al., 2003) who found that the application preemergence herbicides (Dual, Lasso and Frontier) perfect to control weeds in sorghum. However, they can significantly injure the crop.

While, in the pre-planting method, there was a positive correlation, where with increases in 
Table (7): Effect of weed control treatments on panicle length $(\mathrm{cm})$ and weight of grains/panicle (g) in two experiments of application methods in both seasons.

\begin{tabular}{|c|c|c|c|c|c|c|c|c|c|c|}
\hline \multirow{3}{*}{ Treatments } & \multirow{3}{*}{$\begin{array}{l}\text { Rate / } \\
\text { fed. }\end{array}$} & \multirow{3}{*}{$\begin{array}{l}\text { g a.i./ } \\
\text { fed. }\end{array}$} & \multicolumn{4}{|c|}{$\begin{array}{c}\text { Exp.1 } \\
\text { Pre-emergence application } \\
\text { (traditional method) }\end{array}$} & \multicolumn{4}{|c|}{$\begin{array}{c}\text { Exp.2 } \\
\text { Pre-planting application } \\
\text { (improved method) }\end{array}$} \\
\hline & & & \multicolumn{2}{|c|}{$\begin{array}{l}\text { panicle length } \\
(\mathrm{cm})\end{array}$} & \multicolumn{2}{|c|}{$\begin{array}{l}\text { w. of grains / } \\
\text { panicle }(\mathrm{g})\end{array}$} & \multicolumn{2}{|c|}{ panicle length $(\mathrm{cm})$} & \multicolumn{2}{|c|}{$\begin{array}{c}\text { w. of grains / } \\
\text { panicle }(\mathrm{g})\end{array}$} \\
\hline & & & $\begin{array}{c}2018 \\
\text { season }\end{array}$ & $\begin{array}{c}2019 \\
\text { season }\end{array}$ & $\begin{array}{c}2018 \\
\text { season }\end{array}$ & $\begin{array}{c}2019 \\
\text { season }\end{array}$ & $\begin{array}{c}2018 \\
\text { season }\end{array}$ & $\begin{array}{c}2019 \\
\text { season }\end{array}$ & $\begin{array}{c}2018 \\
\text { season }\end{array}$ & $\begin{array}{c}2019 \\
\text { season }\end{array}$ \\
\hline $\begin{array}{l}\text { Butralin } \\
\text { (Amex ) }\end{array}$ & 2.51 & 120 & $20.50 \mathrm{~b}$ & $21.55 \mathrm{~b}$ & $59.7 \mathrm{c}$ & $60.75 \mathrm{c}$ & $26.00 \mathrm{a}$ & $27.25 \mathrm{a}$ & $88.38 \mathrm{a}$ & $89.13 \mathrm{a}$ \\
\hline $\begin{array}{l}\text { Pendimethali } \\
\text { ne (Stomp } \\
\text { Extera) }\end{array}$ & 1.71 & 773.5 & $20.00 \mathrm{~b}$ & $20.38 \mathrm{~b}$ & $66.1 \mathrm{~b}$ & $67.25 \mathrm{~b}$ & $27.25 \mathrm{a}$ & $27.75 \mathrm{a}$ & $89.93 \mathrm{a}$ & $90.23 \mathrm{a}$ \\
\hline $\begin{array}{l}\text { Acetochlor } \\
\text { (Harnnes) }\end{array}$ & 11 & 840 & $20.00 \mathrm{~b}$ & $20.50 \mathrm{~b}$ & $59.6 \mathrm{c}$ & $61.00 \mathrm{c}$ & $26.75 \mathrm{a}$ & $27.25 \mathrm{a}$ & $89.50 \mathrm{a}$ & $90.13 \mathrm{a}$ \\
\hline \multicolumn{3}{|c|}{ Hand hoeing (twice) } & $25.80 \mathrm{a}$ & $26.00 \mathrm{a}$ & $86.6 \mathrm{a}$ & $87.75 \mathrm{a}$ & $24.13 b$ & $25.00 \mathrm{~b}$ & $84.68 \mathrm{~b}$ & $77.20 \mathrm{~b}$ \\
\hline \multicolumn{3}{|c|}{ Untreated weed } & $19.50 \mathrm{~b}$ & $21.00 \mathrm{~b}$ & $56.5 \mathrm{~d}$ & $57.50 \mathrm{~d}$ & $20.75 \mathrm{c}$ & $21.50 \mathrm{c}$ & $69.38 \mathrm{c}$ & $70.58 \mathrm{c}$ \\
\hline
\end{tabular}

Any two means in the same column sharing same letters did not differ significantly by Duncan at $5 \%$ level of probability.

Table (8): Effect of weed control treatments on weight of 1000 grains (g) and grain yield (ardab/fed.) in two experiments of application method in both seasons.

\begin{tabular}{|c|c|c|c|c|c|c|c|c|c|c|}
\hline \multirow{3}{*}{ Treatments } & \multirow{3}{*}{$\begin{array}{l}\text { Rate } \\
\text { / fed. }\end{array}$} & \multirow{3}{*}{$\begin{array}{l}\text { g a.i./ } \\
\text { fed. }\end{array}$} & \multicolumn{4}{|c|}{$\begin{array}{l}\text { Exp.1 } \\
\text { Pre-emergence application } \\
\text { (traditional method) }\end{array}$} & \multicolumn{4}{|c|}{$\begin{array}{c}\text { Exp.2 } \\
\text { Pre-planting application } \\
\text { (improved method) }\end{array}$} \\
\hline & & & \multicolumn{2}{|c|}{$\begin{array}{c}\text { W. of } 1000 \text { grains } \\
(\mathrm{g})\end{array}$} & \multicolumn{2}{|c|}{$\begin{array}{l}\text { Grain yield } \\
\text { (ardab/fed.) }\end{array}$} & \multicolumn{2}{|c|}{$\begin{array}{l}\text { W. of } 1000 \\
\text { grains }(\mathrm{g})\end{array}$} & \multicolumn{2}{|c|}{$\begin{array}{l}\text { Grain yield } \\
\text { (ardab/fed.) }\end{array}$} \\
\hline & & & $\begin{array}{c}2018 \\
\text { season }\end{array}$ & $\begin{array}{c}2019 \\
\text { season }\end{array}$ & $\begin{array}{c}2018 \\
\text { season }\end{array}$ & $\begin{array}{c}2019 \\
\text { season }\end{array}$ & $\begin{array}{c}2018 \\
\text { season }\end{array}$ & $\begin{array}{c}2019 \\
\text { season }\end{array}$ & $\begin{array}{c}2018 \\
\text { season }\end{array}$ & $\begin{array}{c}2019 \\
\text { season }\end{array}$ \\
\hline $\begin{array}{l}\text { Butralin } \\
\text { (Amex ) }\end{array}$ & 2.51 & 120 & $22.0 \mathrm{~b}$ & $23.8 \mathrm{~b}$ & $2.94 \mathrm{c}$ & $2.36 \mathrm{c}$ & $31.5 \mathrm{a}$ & $31.9 \mathrm{a}$ & $17.13 \mathrm{a}$ & $18.13 \mathrm{a}$ \\
\hline $\begin{array}{l}\text { Pendimethaline } \\
\text { (Stomp Extera) }\end{array}$ & 1.71 & 773.5 & $21.0 \mathrm{bc}$ & $24.0 \mathrm{~b}$ & $1.69 \mathrm{~d}$ & $1.81 \mathrm{c}$ & $31.6 \mathrm{a}$ & $32.4 \mathrm{a}$ & $17.52 \mathrm{a}$ & $18.38 \mathrm{a}$ \\
\hline $\begin{array}{l}\text { Acetochlor } \\
\text { (Harnnes) }\end{array}$ & 11 & 840 & $21.3 \mathrm{bc}$ & $23.0 \mathrm{~b}$ & $1.74 \mathrm{~d}$ & $1.99 \mathrm{c}$ & $31.4 \mathrm{a}$ & $32.2 \mathrm{a}$ & $17.35 \mathrm{a}$ & $18.33 \mathrm{a}$ \\
\hline \multicolumn{3}{|c|}{ Hand hoeing (twice) } & $29.5 \mathrm{a}$ & $30.0 \mathrm{a}$ & $14.87 \mathrm{a}$ & $16.01 \mathrm{a}$ & $29.9 \mathrm{~b}$ & $28.3 \mathrm{~b}$ & $15.97 \mathrm{~b}$ & $16.24 \mathrm{~b}$ \\
\hline \multicolumn{3}{|l|}{ Untreated weed } & $20.2 \mathrm{c}$ & $20.7 \mathrm{c}$ & $10.51 \mathrm{~b}$ & $11.40 \mathrm{~b}$ & $20.3 \mathrm{c}$ & $24.3 \mathrm{c}$ & $11.90 \mathrm{c}$ & $12.27 \mathrm{c}$ \\
\hline
\end{tabular}

Any two means in the same column sharing same letters did not differ significantly by Duncan at $5 \%$ level of probability.

the number of plants per plot, yield and its components increased. This explained that these herbicides when exposed for a long time, their degradation can result in decreased toxicity and proceeds to a safe level on sorghum plants. Consequently, crop injury did not occur compared to pre-emergence application method. These results are in agreement with (James et al., 2005) who found that when both the herbicides (Mesotrione and s-metolachlore $(0.33$ and $3.34 \mathrm{ib}$ a.i./gal, respectively)) and (Mesotrione, s-metolachlore and Atrazine (0.27,
2.68 and $1.00 \mathrm{ib}$ a.i/gal, respectively)), were used, they appear to have good potential for use in grain sorghum when applied at 10 or more days pre-plant, but pre-emergence application is risky.

\section{REFERENCES}

Andres A., Concenço G., Schwanke A.M.L., Theisen G. and Melo P.T.B.S. (2009). Periods of weed interference in sorghum grown under lowland conditions. Planta daninha, 27(2):229-234. 
Appleby A.P. and Valverde, B.E. (1989). Behavior of dinitroaniline herbicides in plants. Weed Techn., 3:198-206.

Awika J.M. and Rooney L.W. (2004). Sorghum phytochemicals and their potential aspects on human health. Phytochem., 65:11991221.

Bibard V. (2004). Weed control of sorghum crops: choose the right farming practices in order to facilitate chemical protection. Phytoma. La Défense des Végétaux., 569: 45-48.

Böger P., Matthes B. and Schmalfuss B.J. (2000). Towards the primary target of chloroacetamides-new findings pave the way. Pest Manage. Sci., 56(6):497-508.

BS/EN (15662:2018), Foods of plant origin. Multimethod for the determination of pesticide residues using GC- and LCbased analysis following acetonitrile extraction/partitioning and clean-up by dispersive SPE. Modular Quenchersmethod, $84 \mathrm{p}$.

Dahlberg J., Berenji J., Sikora V. and Latkovic D. (2011). Assessing Sorghum (Sorghum bicolour (L) Moenech) germplasm for new traits: Food, Fuels and Unique Uses. Maydica, 56(1750):85-92.

Delchev G. and Barakova T. (2018). Efficacy of herbicides and herbicide combinations at sorghum (Sorghum bicolor Moench.). Bulg. J. Agric. Sci., 24 (Suppl. 1): 33-39

Dicko M.H., Gruppen H., Traore A.S., Voragen A.G.J. and Van Berkel W.J.H. (2006). Sorghum grain as human food in Africa: relevance of content of starch and amylase activities. Afr. J. Biotech., 5(5): 384 395.

Duncan D.B. (1955). Multiple range and multiple F. Tests. Biometrics, 11: 1- 24.

Dykes L., Rooney W.L. and Rooney L.W. (2013). Evaluation of phenolics and antioxidant activity of black sorghum hybrids. J. Cereal Sci., 58(2):278-283.

Everaarts A.P. (1993). Effect of competition with weeds on the growth, development and yield of sorghum. J. Agric. Sci. Camb., 120:187-196.

FAO (2017). Food and Agriculture Organization Statistics, FAOSTAT. www.fao.org/ faostat.

Gerik T., Brent W.B. and Richard V. (2003). Sorghum Growth and Development.
Agrilife Extension. Productive Rotation on Farms in Texas (PROFT). 1-8p. http ://texasextension.tamu.edu.

Gomez K.A. and Gomez A.A. (1984). Statistical Procedures for Agricultural Research $\left(2^{\text {nd }}\right.$ Ed.). John Wiley and Sons. New York. USA. 680p.

Grichar W.J., Besler B.A. and Brewer K.D. (2005). Weed control and grain sorghum response to post-emergence application of atrazine/pendimethalin and trifluralin. Weed Technology, 19: 999-1003.

Hartzler B. (2020) Absorption of Soil-Applied Herbicides. Herbicide Guide for Iowa Corn and Soybean Production. Iowa State University of Science and Technology. Encyclopedia Article; 1-24.

Jackson M.L. (1960). Soil Chemical Analysis. Printice Hall, Englewood Cliffs, N.J.; U.S.A.

James M.L., Phillip W.S., Patrick W.G. and John C. F. (2005) Soil-Applied Mesotrione in Grain Sorghum. North Central Weed Sci. Soci. Proceed., 60:15

Khaffagy A.E., Moghazy S.M. and Abd Rabboh M.S. (2015). Effect of soil-applied herbicides on damping off by soil borne fungi and weed control in sorghum crop (Sorghum bicolor (L.) Moench). Egypt. J. Agric. Res., 93 (4): 1439-1453.

Mishra J.S. (2015) Weed management in millets: Retrospect and prospects. Indian J. Weed Sci., 47(3): 246-253.

Moges S.M., Girma K., Teal R.K., Freeman K.W., Zhang H. and Arnall D.B. (2007). In-season estimation of grain sorghum yield potential using a hand-held optical sensor. Arch. Agron. Soil Sci., 53(6):617628.

Moomaw R.S., Klein R.N., Martin A., Roeth F., Shea P.J., Wicks G.A. and Wilson R.G. (1992). "G92-1081 Factors That Affect Soil-Applied Herbicides". .Historical Materials from University of NebraskaLincoln Extension. 1220. https:// digitalcommons.unl.edu/extensionhist/1220

Peerzada A.M., Ali H.H. and Chauhan B.S. (2017). Weed management in sorghum (Sorghum bicolor (L.) Moench) using crop competition: A review. Crop Protect. 95:74-80.

Rodrigues A. C. P., Costa N., Cardoso L. A., Campos C. F. and Martins D. (2010). 
Weed interference periods in sorghum crop. Planta daninha, 28(1):23-31.

Schmalfuss B.J., Matthes B., Knuth K. and Böger P. (2000). Inhibition of acyl-CoA elongation by chloroacetamide herbicides in microsomes from leek seedlings. Pestic. Biochem. Physiol., 67: 25-35.

Snedecor G.W. and Cochran W.G. (1980). Statistical method. $7^{\text {th }}$ edition. The Iowa State University Press Ames, Iowa, USA. Täckholm V. (1974). Student flora of Egypt, $2^{\text {nd }}$ Ed., Cairo University, Cairo, Egypt 888 p.

Takano H.K., Rubin R.S., Marques L.H., Tronquini S.M., Fadin D.A. and Kalsing A. (2016) Potential use of herbicides in different sorghum hybrids. Afr. J. Agric. Res., 11(26):2277-2285.
The pesticide manual, PM- Tomlin C.D.S. (2012). (15 ${ }^{\text {th }}$ Ed.). British Crop Production Council, UK.

Vajs S., Leskovsek R., Miklave J., Matko B. and Lesnik M. (2007). Possibilities of chemical weed control in sorghum (Sorghum bicolor (Moench)) fields. $8^{\text {th }}$ Slovenian Conference on Plant Protection, Radenci (Slovenia), pp. 88-98.

Weed Science Society of America (WSSA) (2011). Resistance, WSSA Classification of Herbicide Resistance Mechanism of Action, pp. 1-6! http://www.wssa.net..

Wilde S.A., Corey R.B., Yer J.G.L. and Voigt G.K. (1985). Soil and plant analysis for tree culture. Oxford and IBH Publishing Co., New Delhi India.

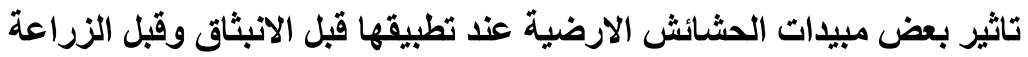

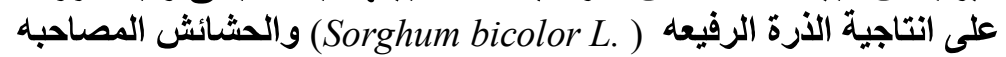

$$
\begin{aligned}
& \text { رشا جمال محمد ابو الحسن - أحمد مصطفى احمد حسانين } \\
& \text { المعمل المركزى لبحوث الحشائش ـ مركز البحوث الزر اعية ـ الجيزه ـ مصر. }
\end{aligned}
$$

اقيمت تجربتان حقليتان فى موسم 2018 وتم تكر ار ها في موسم 2019 بمزر عة الابحاث بمحطة البحوث الزر اعية

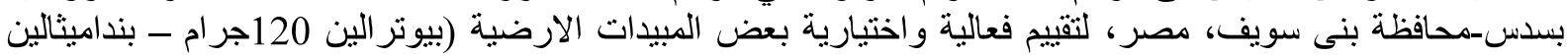

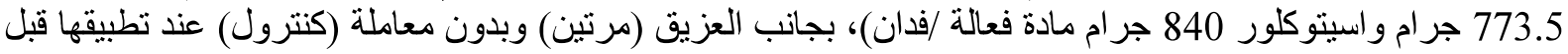

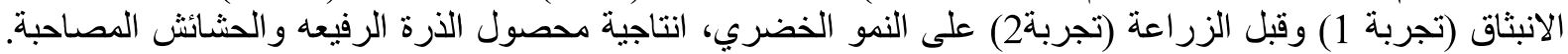

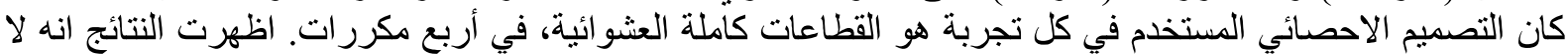
يوجد فروق في الكفاءة الابادة للمبيدات الارضية بين كلا من الطريقتين، حيث اعطت كفاعة ابادة مرضية لمكافحة الحثائش اعطت النتائج فيى معاملة قبل المبل الانبثاق اعلى ضرر لصفات النمو الخضري، حيث كان هناك ارتباط عكسي بين عدد

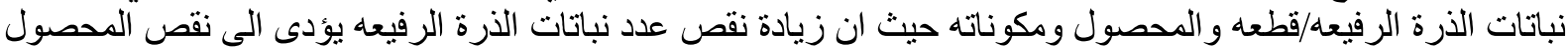

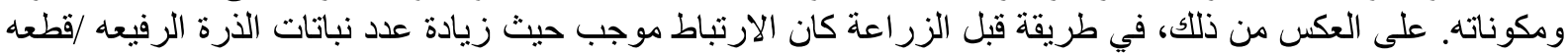

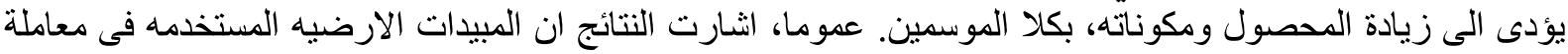

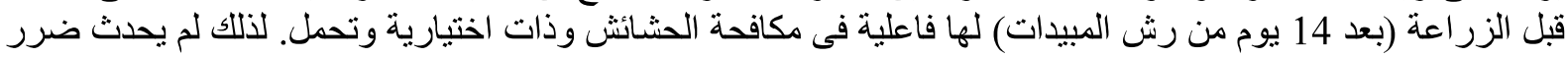

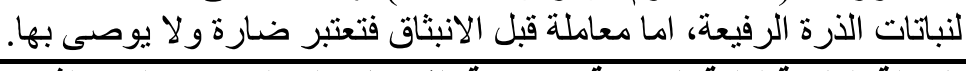

المجلة العلمية لكلية الزراعة - جامعة القاهرة- المجلا (71) العدد الثاني ابريل (2020): 93-85. 